\title{
LINGKUNGAN ALAM SEBAGAI MEDIA \\ PEMBELAJARAN UNTUK MENGENALKAN \\ KEKUASAAN ALLAH PADA ANAK USIA \\ SEKOLAH DASAR DI PONDOK PESANTREN AL \\ MAWADDAH KUDUS
}

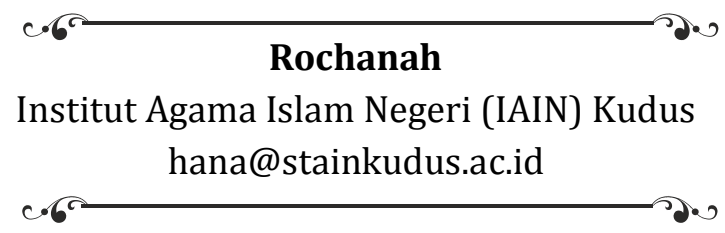

\begin{abstract}
NATURAL ENVIRONMENT AS LEARNING MEDIA FOR INTRODUCING THE GOD'S POWER TO THE ELEMENTARY SCHOOL STUDENTS AT AL MAWADDAH ISLAMIC BOARDING SCHOOL KUDUS. Learning activities are not always in classroom, but it can also occur outside the classroom. Empowering the environment as a learning medium is interesting and fun for students, not only learning directly to nature but students are taught how to know the power of Allah SWT, because this is the cultivation of religious values is very important for elementary school children. The method used in this study is descriptive-analytical research. Data collection techniques through observation, interviews and documentation. The results showed that the concept offered by Al Mawaddah Islamic boarding school to introduce the power of God includes dragon fruit cultivation, living pharmacy, hydroponics, rabbit garden, garrarafa fish therapy.
\end{abstract}

Keywords: the natural environment, Elementary School children, Al Mawaddah.

\footnotetext{
Abstrak

Kegiatan pembelajaran tidak selamanya dilakukan didalam kelas, namun bisa saja terjadi di luar kelas.Memberdayakan lingkungan sebagai media belajar adalah hal yang menarik dan menyenangkan bagi siswa, tidak hanya pembelajaran secara langsung terhadap alam akan tetapi siswa diajarkan bagaimana cara mengenal dan mengetahui kekuasaan Allah SWT, ini karena penanaman nilai
} 


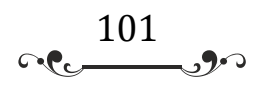

religius sangatlah penting bagi anak sekolah dasar.Metode yang digunakan dalam penelitian ini adalah pdeskriptif-analitis. Teknik pengumpulan data melalui observasi, wawancara dan dokumentasi. Hasil penelitianmenunjukkan bahwa; konsep yang ditawarkan pondok pesantren Al Mawaddah untuk mengenalkan kekuasaan Allah meliputi; budidaya buah naga, apotek hidup, hidroponik, taman kelinci, terapi ikan garra rafa.

Kata Kunci: lingkungan alam, anak Sekolah Dasar, Al Mawaddah

\section{A. Pendahuluan}

Pendidikan memiliki peran penting dalam keberlangsungan proses kehidupan manusia. Mengingat pentingnya pendidikan bagi perkembangan manusia, Islam sebagai agama yang sangat mengutamakan pendidikan memberikan perhatian serius terhadap perkembangan pendidikan bagi kelangsungan hidup manusi. (Baharun, 2016: 2) Pendidikan dan pembelajaran tidak dapat terpisahkan dan menjadi satu kesatuan utuh, dengan semakin tumbuh dan berkembangnya zaman, maka pendidikan dan pembelajaran harus diarahkan kepada pencapaian tujuan pendidikan,

Kegiatan belajar merupakan suatu proses yang harus ada dan terjadi pada setiap orang sepanjang hidupnya (long life eduction). Proses belajar itu terjadi karena adanya interaksi antara pendidik dan peserta didik atau seseorang dengan lingkungannya. (Nata, 2010:151) Oleh karena itu, belajar dapat terjadi kapan saja dan di mana saja, salah satu indikator bahwa seseorang itu telah belajar adalah adanya suatu perubahan tingkah laku pada orang itu yang mungkin disebabkan oleh terjadinya perubahan pada tingkat pengetahuan, keterampilan, atau sikapnya. Adapun pengalaman dalam proses belajar adalah bentuk interaksi antara individu dengan lingkungan.

Pembelajaran yang cenderung masih menggunakan sistem konvensional, kental dengan suasana instruksional dianggap kurang sesuai dengan dinamika perkembangan ilmu pengetahuan dan teknologi yang semakin hari semakin pesat. Sistem pembelajaran konvensional kurang fleksibel dalam mengakomodasi perkembangan 


$$
\text { r.e. } 102
$$

materi kompetensi karena guru harus intensif menyesuaikan materi pelajaran dengan perkembangan teknologi terbaru. (Baharun, 2015: 7)

Tidak tercapainya Kriteria Ketuntasan Minimal (KKM) dalam pembelajaran adalah faktor dari sistem pembelajaran yang masih konvensional. Anak mengantuk atau mengobrol di kelas ketika pembelajaran berlangsung, rasa ingin tahu anak belum terbangun, kurang konsentrasinya anak terhadap penjelasan yang disampaikan oleh guru, anak tidak berani berargumentasi atau bersifat pasif di kelas, dan juga ketertarikan anak dalam mengikuti pelajaran agama. (Baharun, 2016: 5-6) Akibatnya motivasi belajar siswa kurang, padahal motivasi belajar pada anak usia sekolah dasar merupakan hal sangat penting karena awal pertumbuhan pola pikir anak adalah pada usia tersebut.

Paradigma dalam konsep pembelajaran haruslah kegiatan pembelajaran terjadi transfer ilmu dua arah karena bukan hanya guru saja yang terlibat didalamnya, antra guru dengan siswa harus berkerja sama untuk mencapai keberhasilan dalam proses pembelajaran. (Chatib, 2014: 121) Oleh karena itu, pembelajaran harus didesain sedemikian rupa agar kegiatan pembelajaran dapat memacu belajar anak menjadi lebih aktif dan berpusat pada anak (student centered), maka diperlukan metode, strategi, sumber belajar, model dan yang tidak kalah penting adalah media pembelajaran. Apalagi anak usia sekolah dasar yang akan lebih senang jika setiap pembelajaran menarik dan anak mendapatkan pengalaman baru didalamnya. Model pembelajaran tidak hanya menjadikan belajar lebih aktif, akan tetapi juga akan menambah kegairahan sekaligus menghargai perbedaan individu dan beragamnya kecerdasan anak. Salah satu model pembelajaran yang perlu diperhatikan oleh pendidik adalah model pembelajaran langsung dan memanfaatkan lingkungan sekitar sebagai media pembelajaran sehingga didalamnya memberikan pengalaman langsung dan kebermaknaan bagi anak khususnya anak usia sekolah dasar sehingga kegiatan pembelajaran dapat berjalan secara efektif dan efisien sekaligus menyenangkan.

Terciptanya pembelajaran yang efektif jika ditandai dengan sifatnya yang menekankan pada keterlibatan anak secara aktif. Bahwa aktivitas pembelajaran adalah aktivitas fisik dan mental. 


\section{r.e. 103 ,}

(Rohmah, 2015: 266-267) tidak hanya menekankan pada penguasaan pengetahuan tentang apa yang dikerjakan, tetapi lebih menekankan pada internalisasi, tentang apa yang dikerjakan sehingga tertanam dan dipraktikkan dalam kehidupan anak. Dengan pembelajaran langsung terhadap lingkungan akan membuat siswa lebih tahu dan mengenal langsung apa yang diinginkan dari sebuah pembelajaran. Pesantren Al Mawaddah kudus adalah pesantren yang menawarkan pembelajaran dengan media lingkungan alam bagi anak, hal ini sebagai suatu upaya untuk memudahkan guru dalam menyampaikan materi pelajaran pada anak.

Adapun rumusan pertanyaan yang akan dikaji dalam penelitian ini yakni: 1) Media apa saja yang di tawarkan pondok pesantren Al Mawaddah untuk mengenalkan kekuasaan Allah pada anak tingkat dasar?2) Tema apa yang dapat diajarkan melalui media lingkungan alam di pondok pesantren Al Mawaddah pada anak didik tingkat dasar?

Tujuan penelitian yang ingin diwujudkan dalam penelitian ini adalah: 1) Untuk mengetahui jenis media yang di tawarkan pondok pesantren Al Mawaddah untuk mengenalkan kekuasaan Allah pada anak tingkat dasar? 2) Untuk mengetahui tema yang dapat diajarkan melalui media lingkungan alamdi pondok pesantren Al Mawaddah pada anak didik tingkat dasar?

Penelitian dengan Judul "Lingkungan Alam Sebagai Media Pembelajaran Untuk Anak Sekolah Dasar Di Pondok Pesantren Al Mawaddah Honggosoco Jekulo Kudus" dianggap penting karena dengan adanya konsep media menarik yang ditawarkan oleh pondok pesantren Al Mawaddah honggosoco Kudus, maka akan memudahkan anak untuk lebih mengenal dan memahami akan besarnya kekuasaan Allah sebagai Sang Pencipta. Anak akan lebih memahami bahwa Allah berkuasa menciptakan apapun yang Ia kehendaki.Anak akan langsung dapat mengamati beragamnya kekuasaan Allah yang begitu menakjubkan. Hal ini berbeda ketika anak mendapatkan penjelasan tentang kekuasaan Allah namun tidak dibarengi dengan pengamatan secara langsung.

Diantara beberapa penelitian yang telah dikaji oleh penelitipeneliti sebelumnya berkaitan dengan tema penelitian yang hampir sama dengan penelitian yang peneliti kaji yakni penelitian yang 


$$
\text { r.e. } 104
$$

dilakukan oleh Roso Sugiyanto, Pemanfaatan Media Lingkungan Untuk Meningkatkan Hasil Belajar IPS Siswa Sekolah Dasar Negeri 4 Tanah Putih Kecamatan Telawang Kabupaten Kotawaringin Timur. Hasil penelitian menunjukkan penggunaan media lingkungan pada mata pelajaran IPS dapat meningkatkan hasil belajar IPS siswa dikelas IV SD Negeri 4 Tanah Putih, Kecamatan Telawang Kabupaten Kotawaringin Timur tahun ajaran 2014/2015. (Sugiyanto, 2015: 30)

Juga penelitian yang dilakukan oleh Syofnidah Ifrianti dengan judul "Pemanfaatan lingkungan sekitar sebagai media pembelajaran IPS untuk meningkatkan aktivitas dan hasil belajar anak kelas III MIN 10 Bandar Lampung 218". Penelitian ini merupakan Penelitian Tindakan Kelas (PTK) yang terdiri dari dua siklus. Permasalahan dalam penelitian ini adalah masih rendahnya aktivitas dan hasil belajar anak kelas III MIN 10Bandar Lampung.Oleh karena itupeneliti berupaya meningkatkan aktivitas dan hasil belajar anak dengan menggunakan lingkungan sekitar sebagai media pembelajaran. (Ifrianti, 2016: 218).

Ramadhani, Tahmid Sabri, Siti Halidjah dengan judul; "Pemanfaatan Media Lingkungan Sekitar Untuk Meningkatkan Keterampilan Menulis Karangan Deskripsi Siswa Kelas V”. Skor RPP keterampilan menulis karangan deskripsi menggunakan media lingkungan sekitar sebagai sumber belajar mengalami peningkatan. Pembelajaran siklus I mengalami peningkatan skor menjadi 14,52 dengan rata-ratanya 3,63, pada siklus II meningkat 15,68 dengan rata-ratanya 3,92 (Halidjah, tt: 1)

Dari ketiga penelitian yang telah dilakukan oleh beberapa peneliti diatas, sisi kebaruan (novelty) dalam penelitian ini adalah dalam hal tujuan yang ingin dicapai. Dalam penelitian yang dilakukan oleh Ramadhani, tujuan penelitiannya yakni mendeskripsikan peningkatan keterampilan menulis karangan siswa kelas $\mathrm{V}$ melalui pemanfaatan lingkungan sekitar sebagai sumber belajar. Dalam penelitian Syofnidah Ifrianti dan Roso Sugiyanto tujuan yang hendak dicapai dalam kedua penelitian tersebut yakni meningkatkan aktivitas dan hasil belajar anak dengan menggunakan lingkungan sekitar sebagai media pembelajaran IPS.Adapun dalam penelitian ini, tujuan yang ingin dicapai yakni mengenalkan dan memahamkan anak akan beragamnya ciptaan Allah. 


$$
\text { r.e. }
$$

Penelitian berjudul "Lingkungan Alam Sebagai Media Pembelajaran Untuk Mengenalkan Kekuasaan Allah Pada Anak Usia Sekolah Dasar Di Pondok Pesantren Al Mawaddah Kudus" berkontribusi secara teoritis dan praktis: Penelitian ini diharapkan dapat bermanfaat sebagai berikut: 1) Sebagai kontribusi untuk membentuk dan memupuk kecintaan anak pada Allah. 2) Sebagai media/ sarana untuk mengenalkan kekuasaan Allah. 3) Sebagai referensi bagi guru dalam memudahkan penyampaian materi kepada anak.

\section{Metode Penelitian}

Jenis penelitian ini merupakan penelitian deskriptif-analitis tentang pemanfaatan lingkungan alam untuk mengenalkan kekuasaan Allah. Prosesnya berupa pengumpulan dan penyusunan data, serta analisis dan penafsiran data tersebut.Penelitian ini mengunakan pendekatan kualitatif yang bertujuan untuk meneliti pada kondisi obyek yang alamiah, yakni memfasilitasi anak pada tingkat dasar untuk memanfaatkan alam sebagai media belajar. Peneliti berfungsi sebagai instrumen kunci, dan analisis data bersifat induktif. Hasil penelitian kualitatif lebih menekankan makna daripada generalisasi. (Sugiyono, 2016: 13-14)

Teknik pengumpulan data melalui: 1) Observasi, dilakukan untuk mengamati perilaku manusia dalam situasi tertentu untuk mendapatkan informasi tentang fenomena yang diinginkan (Sugiyono, 2016: 196) Wawancara, dilakukan secara semi terstruktur dan tak terstruktur. 3) Dokumentasi, bisa berbentuk tulisan, gambar atau karya monumental dari seseorang. Dokumentasi dalam penelitian ini berupa buku, artikel maupun penelitian sebelumnya yang terkait dengan tema, maupun dokumentasi yang berbentuk gambar, grafik dan lain-lain. (Sugiyono, 2016: 327)

\section{B. Pembahasan}

\section{Landasan Teori}

\section{a. Media Pembelajaran}

Media berasal dari bahasa Latin, yaitu medium yang secara harfiah berarti 'tengah','perantara'. Medeo adalah pengantar atau perantara dari pengirim ke penirima Pesan. National Education Assosiation (NEA) mendefinisikan media sebagai benda yang dapat 


\section{6 .es}

dimanipulasikan, dilihat, didengar, dibaca, atau dibicarakan. Teknologi dan komunikasi pendidikan (AECT) di Amerika membatasi media dari segala bentuk dan saluran yang digunakan oleh orang untuk menyalurkan pesan ataau informasi secara tidak langsung. (Sadiman, 2012: 6).

Media pembelajaran adalah alat bantu pembelajaran yang digunakan untuk membantu melancarkan jalannya pembelajaran agar tujuan yang diharapkan dapat tercapai. Guru dalam meneggunakan media pembelajaran harus sesuai dengan tata aturannya, diantaranya yakni dengan memperhatikan perkembangan dan karakteristik anak yang akan menggunakan media. Hal ini dilakukan agar tujuan pembelajaran dapat tercapai secara maksimal sesuai dengan yang diharapkan. (Djamarah, 2006:122)

Menurut penjelasan Gagne (1970), sebagaimana dikutip oleh Arief Sardiman dalam bukuny dijelaskan bahwa memaknai media sebagai sesuatu yang dapat digunakan untuk menyalurkan pesan dari pengirim ke penerima sehingga dapat merangsang fikiran, perasaan, perhatian, dan minat serta perhatian anak sedemikian rupa sehingga proses belajar terjadi. (Sadiman, 2012: 7)

Bisa dipahami bahwa, media adalah alat bantu apa yang dapat dijadikan sebagai penyalur pesan guna mencapai tujuan pembelajaran. Dengan demikian, media pembelajaran berfungsi untuk mempertingggi daya serap peemahaman anak terhadap materi pembelajaran karena keberhasilan pembelajaran sangat ditentukan oleh dua faktor utama, yaitu metode dan media. Kedua komponen ini saling berkaitan dan tidak bisa dipisahkan. (Baharun, 2016: 6) Media pembelajaran, sebagai alat bantu dalam proses pembelajaran, memiliki beberapa manfaat di antaranya ;

a. Pengajaran lebih menarik perhatian anak saat proses pembelajar sehingga dapat menumbuhkan motivasi belajar;

b. Media sebagai pendukun bahan pengajaran akan lebih jelas maknanya, sehingga dapat dipahami materi yang diajarkan, serta memungkinkan tujuan pembelajaran dengan sempurna;

c. Media pembelajaran dapat bervariasi, tidak hanya komunikasi verbal melalui penuturan kata-kata lisan pengajar saja, pembelajaran tidak bosan, dan pengajar tidak kehabisan tenaga. 


\section{r.e. 107}

Peranan media dalam berkontribusi meningkatkan mutu dan kualitas pembelajaran sangat besar. Kehadiran media tidak hanya membantu pengajar dalam menyampaikan materi ajarnya, tetapi memberikan nilai tambah pada kegiatan pembelajaran. sebagaimana dikutip oleh Uno dalam bukunya yang menjabarkan sejumlah kontribusi media dalam kegiatan pembelajaran yang meliputi: penyajian materi ajar menjadi lebih standar, kegiatan pembelajaran menjadi lebih menarik, kegiatan belajar dapat menjadi lebih interaktif, waktu yang dibutuhkan untuk pembelajaran dapat dikurangi, kualitas belajar dapat ditingkatkan, pembelajaran dapat disajikan di mana dan kapan saja sesuai dengan yang diinginkan, meningkatkan sifat positif anak dan proses belajar menjadi lebih baik, dan memberikan nilai positif bagi pengajar. (Uno, 2011: 124)

Media bukan hanya berupa alat atau bahan, melainkan halhal lain yang memungkinkan anak dapat memperoleh pengetahuan baru. Hal ini sesuai dengan pernyataan Gerlach yang menyatakan bahwa secara umum media itu meliputi orang, bahan, peralatan, atau kegiatan yang menciptakan kondisi yang memungkinkan dalam proses interaksi.(Baharun, 2016: 8)

Guru harus memiliki pengetahuan dan pemahaman yang cukup tentang media pengajaran. Salah satu upaya seorang guru sebagai penyampai informasi adalah penggunaan media pembelajaran yang tepat dalam menyampaikan pesan-pesannya. (Sanjaya, 2005: 160) Terlebih lagi pada kegiatan pembelajaran saat ini yang menekankan pada keterampilan proses dan active learning, maka peranan media pembelajaran menjadi semakin penting. Penggunaan media sangat dianjurkan bagi anak yang belum dapat menerima pesan yang disampaikan guru.

Oleh karena itu, salah satu prinsip penggunaan media pembelajaran adalah anak harus dipersiapkan dan diperlakukan sebagai peserta yang aktif serta ikut bertanggung jawab dalam seluruh aktivitas kegiatan pembelajaran, supaya mampu menggugah motivasi dan minat belajar anak dalam kegiatan belajar mengajar.

Media memiliki peranan penting dalam proses pembelajaran sebagai alat pengembangan wawasan anak yang meletakkan cara berpikir konkret dalam kegiatan belajar mengajar dengan memahami kondisi psikologis siswa, tujuan, metode, dan kelengkapan alat bantu. 


$$
\text { r.c. }
$$

Fathurrohman (2009) memberi gambaran lebih detail dari manfaat penggunaan media dalam proses pembelajaran, (a) Menarik perhatian siswa, (b) Membantu untuk mempercepat pemahaman, (b) Memperjelas penyajian pesan agar tidak bersifat verbalistis (dalam bentuk kata-kata tertulis atau lisan), (c) Mengatasi keterbatasan ruang, (d) Pembelajaran lebih komunikatif dan produktif, (e) Waktu pembelajaran bisa dikondisikan, (f) Menghilangkan kebosanan pada siswa dan meningkatkan motivasi siswa. (Fathurrohman, Pupuh dan M. Sobri Sutikno, 2009)

\section{b. Anak Usia Sekolah Dasar (SD)}

Masa perkembangan anak perlu di perhatikan secara serius dan anak sangatlah pesat dalam perkembangan pengetahun. Late Cildhood dalam istilah lingkup pendidikan adalah anak usia sekolah dasar.(Hurlock, 2009: 146) Pada usia ini anak-anak diharapkan mendapatkan dasar-dasar pengetahuan yang dianggap penting sebagai penyesuaian saat menginjak usia dewasa, tidak hanya muluk pendidikan kulikuler akan tetapi semua pendidikan yang merangsang pertumbuhan pola berpikir anak juga perlu diperhatikan oleh pendidik seperti ekstakulikuler dan contectual learning.

Masa kanak-kanak juga disebut dengan masa laten, istilah laten diambil oleh Sigmund frued karena sifat anak yang mengendap. Menurut frued masa usia laten di bagi menjadi dua, yaitu masa kelas atas dan masa kelas rendah. (Wiyani, 2013: 70) Masa kelas rendah merupakan saat anak duduk pada kelas 1, 2 dn 3 aatau usia 6 sampai 9 tahun. Dan masa kelas atas adalah saat nak usia 9 hingga 13 tahun atau sudah menginjak kelas 4 sampai 6 sekolah dasar.

Usia anak sekolah dasar merupakan periode kritis dalam dorongan berprestasi. Suatu masa dimana anak terbiasa membentuk sukses. Sebab kesuksesan dimasa kanak-kanak akan mempengaruhi kesuksesanya dimasa dewasa nanti. Kebiasaan bekerja diatas kemampuan pola berpikirnya akan mempengaruhi pola akademik dan cenderung akan mendapatkan prestasi secara berkelanjutan. (Hurlock, 2009: 147) Usia 6 sampai dengan 12 tahun adalah masamasa yang sangat bagus untuk perkembangan. Seorang anak harus mampu menyelesaikan tugas-tugas perkembangan sehingga tidak menghambat tugas-tugas perkembangan selanjutnya. 


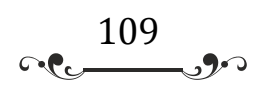

Tugas perkembangan pada usia ini dalam kaitannya dengan pendidikan atau pembelajaran adalah siswa mampu membaca, menulis, berhitung, dan perkembangan sikap. Semuanya adalah tugas tanggung jawab guru dan orang tua untuk selalu mengawasi seluruh proses perkembangan. Meskipun peranan orang tua sangat penting didalam pembentukan sebelumnya, tetapi peranan kelompok atau lembaga inilah yang akan menentukan keberhasilan, sebab disekolahlah anak mendapatkan pengalaman baru dalam belajar. (Hurlock, 2009: 146-147)

Pengalaman belajar dalam sebuah kelompok serta pengawasan dalam kelompok oleh guru sangatlah penting. Pertumbuhan anak dalam komunikasi menjadi prioritas sebab berbicara adalah sarana penting bagi anak dalam satu kelompok (sekolah). Dengan mengetahui cara berkomunikasi dengan baik anak akan dapat memahami apa yang dikatakan oleh orang lain dan teman-teman paham apa yang sedag dibicarakan (arah pembicaraan jelas). Sebaliknya, kalau anak tidak mengerti apa yang dikatakan oleh orang lain dan bahkan yang dibicarakan sama sekali tidak berhubungan dengan apa yang dibicarakaan oleh teman-teman satu kelompoknya, maka ia tidak diterima dalam kelompok tersebut. Perkembangan anak sekolah dasar dapat dibedakan dalam aspek kogntif (kecerdasan), afektif (perasaan) dan Psikomotorik (gerak). (wiyani, 2013: 71)

Dalam perkembangan kognitif artinya terdapat perubahan pola pikir atau intelektal anak. Secara umum tahapan kognitif dijelaskan oleh Bloom yaitu, mengetahui, memahami, menerapkan, menganalisis dan mengevalusi. Menurut J. Piaget bahwa pemikiran anak usia sekolah dasar masuk dalam tahapan pemikiran operasional kongret, maksudnya segala aktivitas mental terfokus pada obyek nyata atau kejadian yang pernah dialaminya. Dapat dikatakan anak sekolah dasar sudah mampu menyelesaikan permasalahan dengan urutan sebab akibat dan dengan cara yang beragam. Kemampuan berpikir anak sekolah dasar hanya sebatas hal yang realistis dan belum mampu memahami konsep yang abstrak. Perhatian anak sekolah dasar tertuju pada hal yang praktis dan kogret sehingga mereka mempunyai rasa ingin tahu yang tinggi terhadap suatu hal. 


\section{reces}

Perkembangan aspek afektif pada anak sekolah dasar sangat berhubungan dengan emosi, perasaan, system nilai serta sikap hati yang menunjukkan sikap penerimaan dan penolakan terhadap sesuatu. Kurikulum 2013 menjelaskan kemampuan afektif dalam lima tahapan yaitu menerima, menjalankan, menghargai, menghayati dan mengamalkan.

Kemampuan emosional anak pada usia akhir kanak-kanak hampir sama dengan periode kanak-kanak awal, hanya saja perubahan pengambilan sikap atau situasi emosi yang muncul akan lebih beragam sesuai dengan pengalaman belajarnya (tingkat kematangnya). Keadaan usia akhir masa kanak-kanak ada waktu dimana emosi yang sangat tinggi muncul atau mengalami emosi yang hebat. Keadaan ini muncul karena disebabkan faktor dari diri sendiri, keluarga dan teman sebaya. (wiyani, 2013: 73-74)

Pada perkembangan aspek psikomotorik terkait dengan segala bentuk kegiatan motorik yang berhubungan dengan anggota tubuh atau tindakan yang memerlukan koordinasi antara tubuh dengan otak. Keseimbangan anggota tubuh menjadi kunci keberhasilan dan tumbuh kembang anak.(Monks, 2014: 176) Dalam kajian kurikulum 2013 ada tujuh tahapan dalam perkembangan psikomotor yaitu mengamati, menanya, mencoba, mengolah, menyaji, menalar dan mencipta. Proses perkembangan yang nampak adalah pada ukuran tubuh, proporsi tubuh, ciri kelamin primer maupun sekunder. (Wiyani, 2013: 74) Lingkungan dan status ekonomi keluarga juga sangat mempengaruhi perkembangan psikomotorik anak. Keterampilan menolong dan bermain pada anak tingkatan sosial diatas akan lebih rendah dibandingkan dengan yang sosial ekonominya rendah.

\section{c. Lingkungan Alam}

Lingkungan sangat berperan dalam pertumbuhan dan perkembangan anak. Lingkungan adalah keluarga yang mengasuh dan membesarkan anak, sekolah tempat mendidik, masyarakat tempat anak bergaul juga bermain sehari-hari dan keadaan alam sekitar dengan iklimnya, flora faunanya. Besar kecilnya pengaruh lingkungan terhadap pertumbuhan dan perkembangannya bergantung pada lingkungan anak itu sendiri serta jasmani dan rohaninya. (Ifrianti, 2016: 220) 


\section{reces}

Lingkungan sebagai media pendidikan merupakan faktor yang penting dan mempengaruhi tingkah laku individu. Keberadaan lingkungan disekitar anak dapat digunakan sebagai media pembelajaran mereka. Lingkungan pembelajaran meliputi masyarakat dan segala bentuk fisik yang dapat dimanfaatkan untuk dijadikan sebagai bahan pembelajaran. Jadi, media pembelajaran lingkungan adalah pemahaman terhadap tingkah laku suatu objek tertentu yang dapat dilihat secara langsung dan ada keterkaitan dengn materi yang ada disekolah, sehingga dari pengamatan anak dapat mendapatkan pengetahuan baru di lingkungan mereka. (Baharun, 2016: 7)

Lingkungan alam adalah segala sesuatu yang sifatnya alamiah (natural) seperti keadaan geografis, iklim, suhu udara, musim, curah hujan, flora, fauna, dan sumber daya alam (air, hutan, tanah, batubatuan dan lain- lain). Aspek-aspek tersebut dapat dipelajari oleh anak secara langsung melalui cara-cara tertentu. Dengan mempelajari lingkungan alam diharapkan para anak dalam kegiatan pembelajaran dapat lebih memahami materi di sekolah serta dapat menumbuhkan cinta terhadap alam dan mengetahui kekuasaan Allah SWT. dan tumbuh kesadaran untuk menjaga dan memelihara kelestarian lingkungan, serta tetap menjaga kelestarian kemampuan sumber daya alam bagi kehidupan manusia. (Baharun, 2016: 8).

\section{Hasil Penelitian}

Pondok Pesantren al-Mawaddah Kudus kehadirannya berawal dari suatu komitemen yang besar dan kesadaran yang tertanam dari pengasuhnya untuk mengamalkan ilmu yang telah di dapatnya agar dapat memberikan sesuatu yang bermanfaat dunia dan akhirat. Pondok Pesantren al-Mawaddah Honggosoco Jekulo Kudus didirikan sekitar tahun 2008 oleh KH. Sofyan Hadi, Lc., M.A. pendidikan sarjananya beliau dapatkan dari Fakultas Syari'ah walQanun al-Azhar Kairo, dan gelar S2 nya beliau raih dari Fakultas Interregious and Cross-Cultural Studies UGM Yogyakarta. Dalam menegakan dan menghidupkan agama Islam, beliau mendapatkan dukungan yang penuh dari istrinya $\mathrm{Hj}$. Siti Khodijah al-Hafidzah, beliau adalah alumni dari Pondok Pesantren Yanbu'ul Qur'an Kudus. Selain dukungan dari istrinya, beliau juga mendapat dukungan dari keluarganya dan masyarakat sekitar. 


\section{r.e.c. 112}

Kurikulum pesantren yang ditawarkan oleh pesantren Al Mawaddah honggosoco Kudus memadukan kearifan lokal sebagaimana yang diajarkan oleh Sunan Kudus, yakni GUSJIGANG (akronim dari : bagus akhlak lan budine, pinter ngaji lan dagang) yang berarti: Gus (bagus). Melalui kata "gus" ini diharapkan agar para santri memiliki akhlak dan budi pekerti yang luhur. Ji (ngaji). Para santri di ajarkan tentang ilmu agama agar memiliki pengetahuan yang mendalam tentang ilmu, baik ilmu agam maupun ilmu dunia. Hal ini dimaksudkan agar santri mempunyai bekal yang kuat dalam menjalani kehidupan di dunia dan akhirat nanti. Gang (dagang). Para santri diajarkan untuk berdagang sebagaimana yang telah diajarkan oleh sunan kudus dalam mendakwahkan dan mensyiarkan agama Islam di kota kudus. Kemampuan berdagang diajarkan kepada santri sebagai bekal untuk hidup di dunia. Hal ini karena dalam agama Islam diajarakan untuk menerapkan sikap "wasathiyah" yaitu sikap menyeimbangkan kehidupan dunia dan akhirat. Ini artinya, bukan hanya urusan akirat saja yang diperhatikan dalam agama Islam, namun juga urusan dunia. Karena pada dasarnya orang Islam dianjurkan untuk menjadi "kaya" agar mendorong suksesnya dalam menghidupkan agama Islam. Setidaknya itulah yang ditawarkan oleh pondok pesantren $\mathrm{Al} \mathrm{Mawaddah} \mathrm{kepada} \mathrm{santrinya.}$

Konsep yang disajikan oleh pondok pesantren Al-Mawaddah dalam bidang pendidikan mengintegrasikan antara pendidikan formal dan non formal yang bertujuan adanya perubahan dalam diri santri, yakni dari tidak bisa menjadi bisa, dari belum tau menjadi tau dan dari bisa menjadi lebih bisa. Hal ini sebagaimana termuat dalam visi dan misi pondok pesantren Al Mawaddah; Visi; Menjadi institusi global yang mendorong lahirnya peradaban yang sukses mulia. Misi; menginspirasi dan memberikan yang terbaik dalam proses pemberdayaan untuk meraih puncak prestasi, dengan berpijak pada prinsip-prinsip universal serta kearifan lokal.

Pondok pensantren Al Mawaddah Kudus berjalan aktif di dalam perananya untuk menjadikan lingkungan sebagai media pembelajaran. Lingkungan alam dan buatan yang dibentuk oleh ponpes Al Mawaddah menarik perhatian anak dalam belajar dan bermain. Hal ini bertujuan membugarkan kembali semangat anak 


$$
\text { recus }
$$

untuk belajar dan memperoleh pnemuan baru dalam interaksi dengan lingkungan alam tersebut.

Media pembelajaran yang disediakan oleh Al Mawaddah mengenalkan bagaimana kekuasaan Allah, yakni melalui mahluk atau tumbuhan disekeliling lingkungan pembelajaran anak. Allah sebagai sang Kholiq(Maha Pencipta) menciptakan berbagai macam hewan dan tumbuhan. Tema yang terkait dengan media yang ditawarkan $\mathrm{Al}$ Mawaddah yakni dalam mata pelajaran Aqidah Akhlak dengan tema Asmaul Husna dalam lafalnya "Al Khaliq" (Sang Pencipta), selain itu juga termuat dalam mata pelajaran Ilmu Pengetahuan Alam (IPA) dalam tema tumbuhan dan binatang. Melalui media lingkungan alam tersebut akan membantu guru dalam menjelaskan materi terkait tema-tema tersebut. Konsep itulah yang dibangun oleh Al Mawaddah melalui berbagai macam wahana pembelajaran, diantaranya;

\section{a. Bercocok Tanam Melalui Hidroponik}

Hidroponik adalah menanam dengan menggunakan air, bukan dengan menggunakan tanah. Berbagai jenis tanaman yang dikembangkan di pondok pesantren Mawaddah melalui hidroponik yakni; pakcoi, bayam merah, kangkung, selada merah dan selada hijau, daun mint dan lain- lain.

Dari sini anak diajarkan bahwa kekuasaan allah begitu luasnya. Bahwa tanaman tidak selalu harus tumbuh di tanah, melainkan juga bisa tumbuh di air. Diantara tanaman hidroponik tersebut, ada yang digunakan untuk kebutuhan sehari-hari anak, yakni daun mint yang digunakan untuk bahan pembuatan pasta gigi.

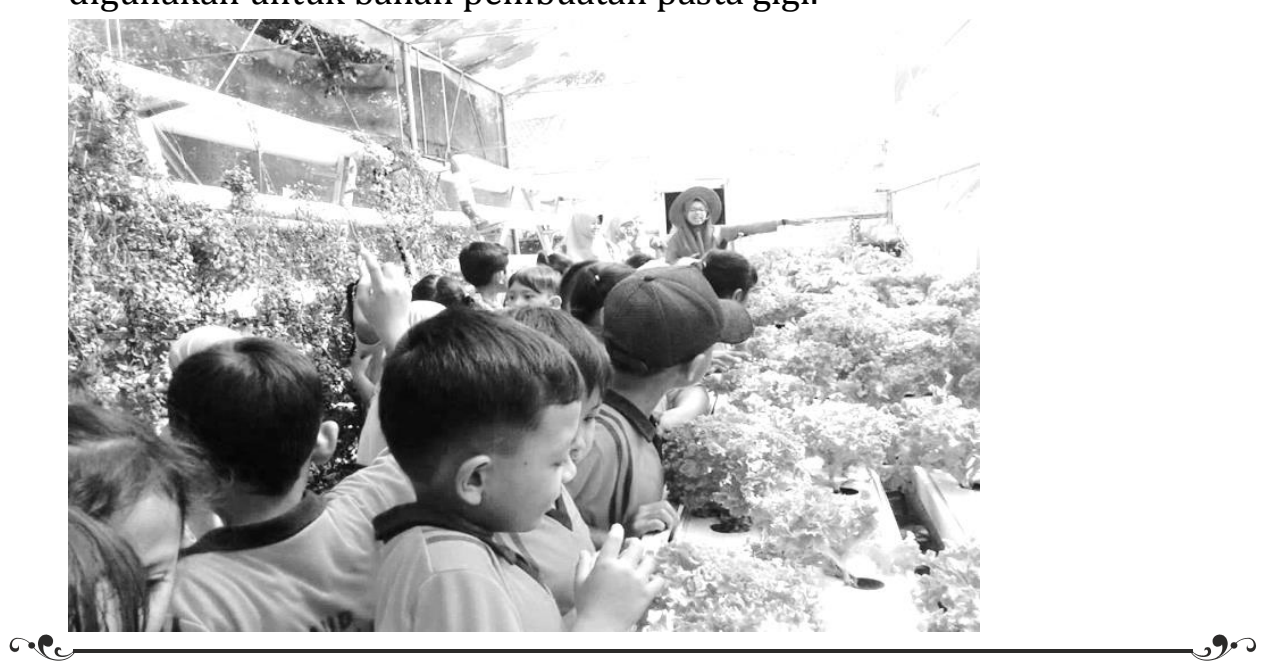




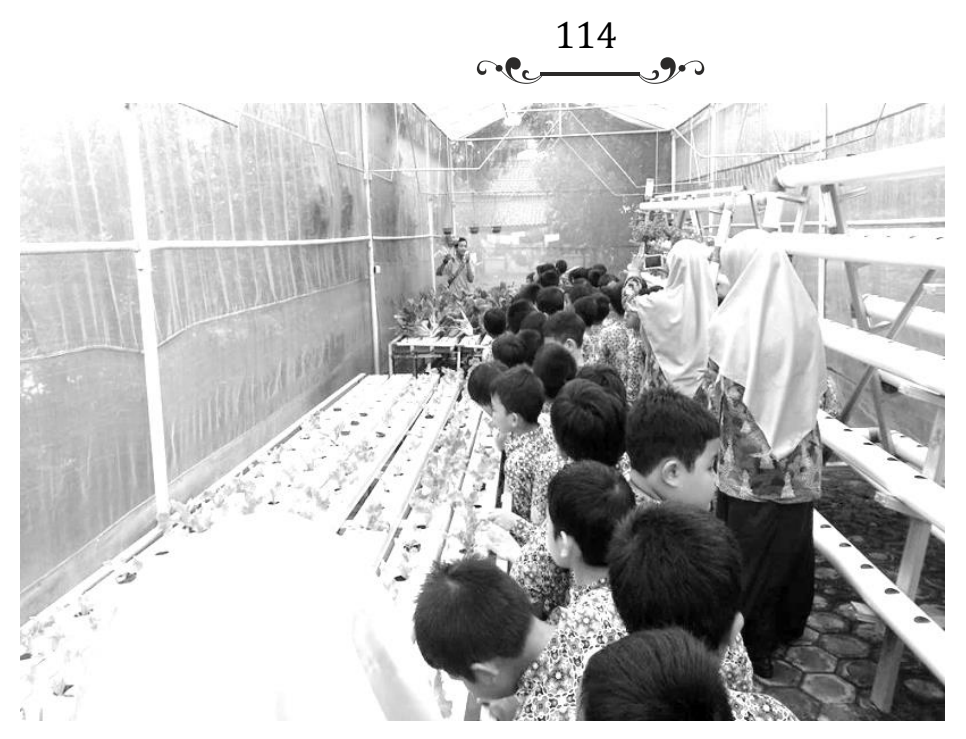

\section{b. Budidaya Buah Naga}

Budidaya buah naga merupakan budidaya terbesar yang dikembangkan oleh pesantren $\mathrm{Al}$ Mawaddah. Setiap pengunjung pesantren Al Mawaddah, dalam hal ini anak diperkenankan untuk membawa oleh-oleh buah naga yang bisa dipetiknya secara langsung di perkebunan buah naga untuk dibawa pulang. Hal ini mengajarkan kepada anak sejak dini bahwa berbagi itu indah, sebagaimana hadits "al yadul ulya khoirun min yadissufla". Selain bisa dikonsumsi secara langsung, buah naga juga bisa diolah menjadi berbagai jenis makanan; keripik buahnaga, selai buah naga, dan sirup buah naga. Dari sini anak diajarkan bahwa dari satu jenis tanaman ciptaan Allah bisa diolah menjadi begitu beragamnya jenis makanan.

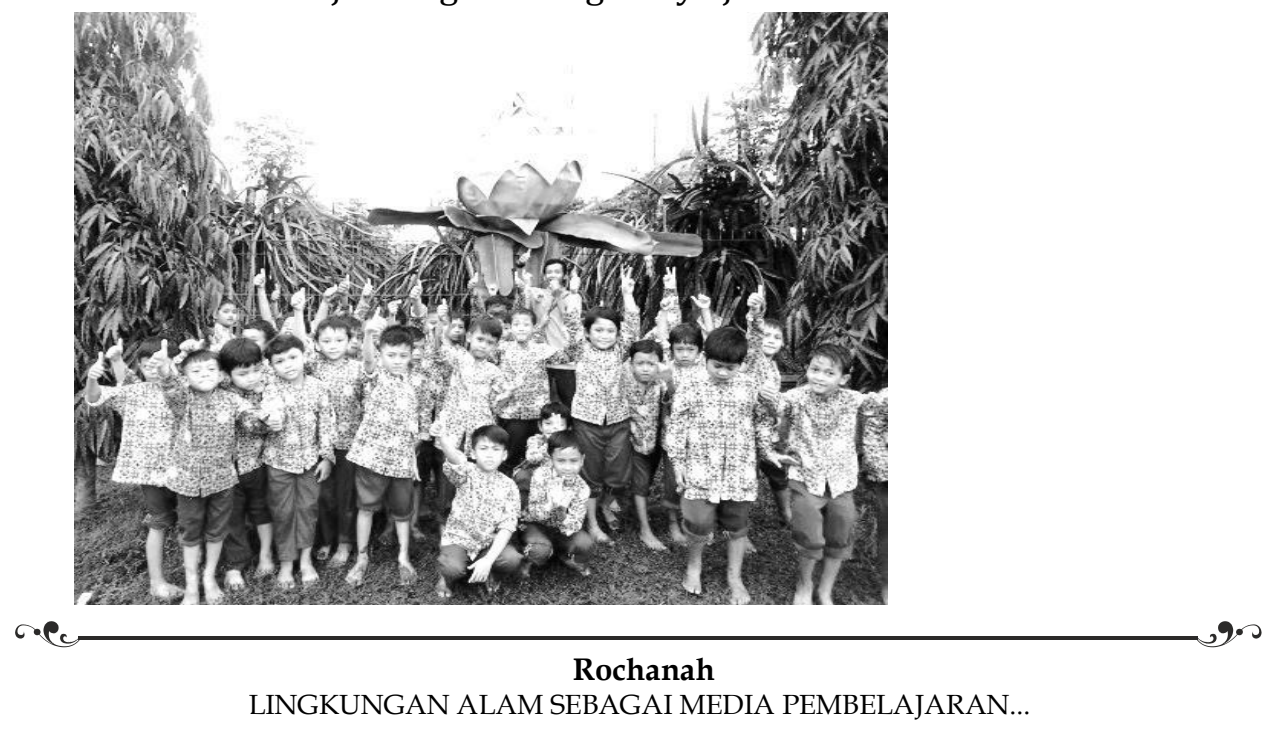




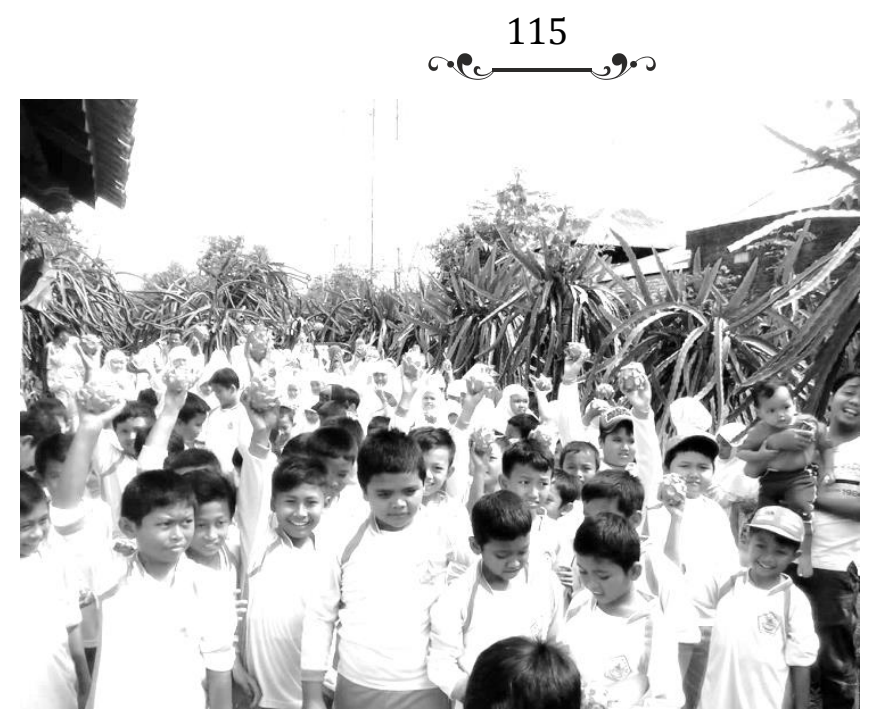

\section{c. Apotek Hidup}

Tanaman-tanaman tersebut dioalah menjadi jamu instant, temulawak instan, jahe instan, dan permen. Melalui apotek hidup, anak diajarkan bahwa ada berbagai jenis tanamanyang tumbuh di sekitar kita yang dapat dimanfaatkan untuk menjaga kesehatan. Sebagaimana agama Islam sangat menganjurkan pemeluknya untuk selalu menjaga kesehatan. Dalam proses menjelaskan tentang fungsinya masing-masing, anak secara tidak sadar bahwa ia sedang menerima pembelajaran dengan cara yang sangat menarik, yaitu dengan media lingkungan.

\section{d. Terapi Ikan Garra Rufa}

Selain dapat menikmati keindahan tanaman-tanaman yang memang sengaja di budidayakan oleh pondok pesantren Al Mawaddah, anak (pengunjung) juga ditawarkan untuk bermain di kolam ikan garra rufa, yakni terapi ikan garra rufa. Ikan memiliki banyak fungsi bagi manusia, selain bisa digunakan untuk terapi kecantikan kaki (pedicure), ikan ini juga bisa membantu proses pengelupasan kulit mati secara alamiah, membantu melembabkan kulit, membantu mengurangi bekas luka, meremajakan kulit sehingga kulit akan terlihat lebih halusdan bersih.

Melalui ikan garra rufa ini, anak mendapatkan pengetahuan bahwa makhluk Allah sekecil apapun dapat memberikan manfaat positif bagi manusia. Bahwa ikan bukan hanya binatang untuk dikonsumsi sebagai lauk pauk saja, melainkan dapat memberikan segudang 


$$
\text { reces }
$$

manfaat untuk kesehatan manusia. Karenanya kita harus menjaga lingkungan alam agar tetap terjaga dan lestari.

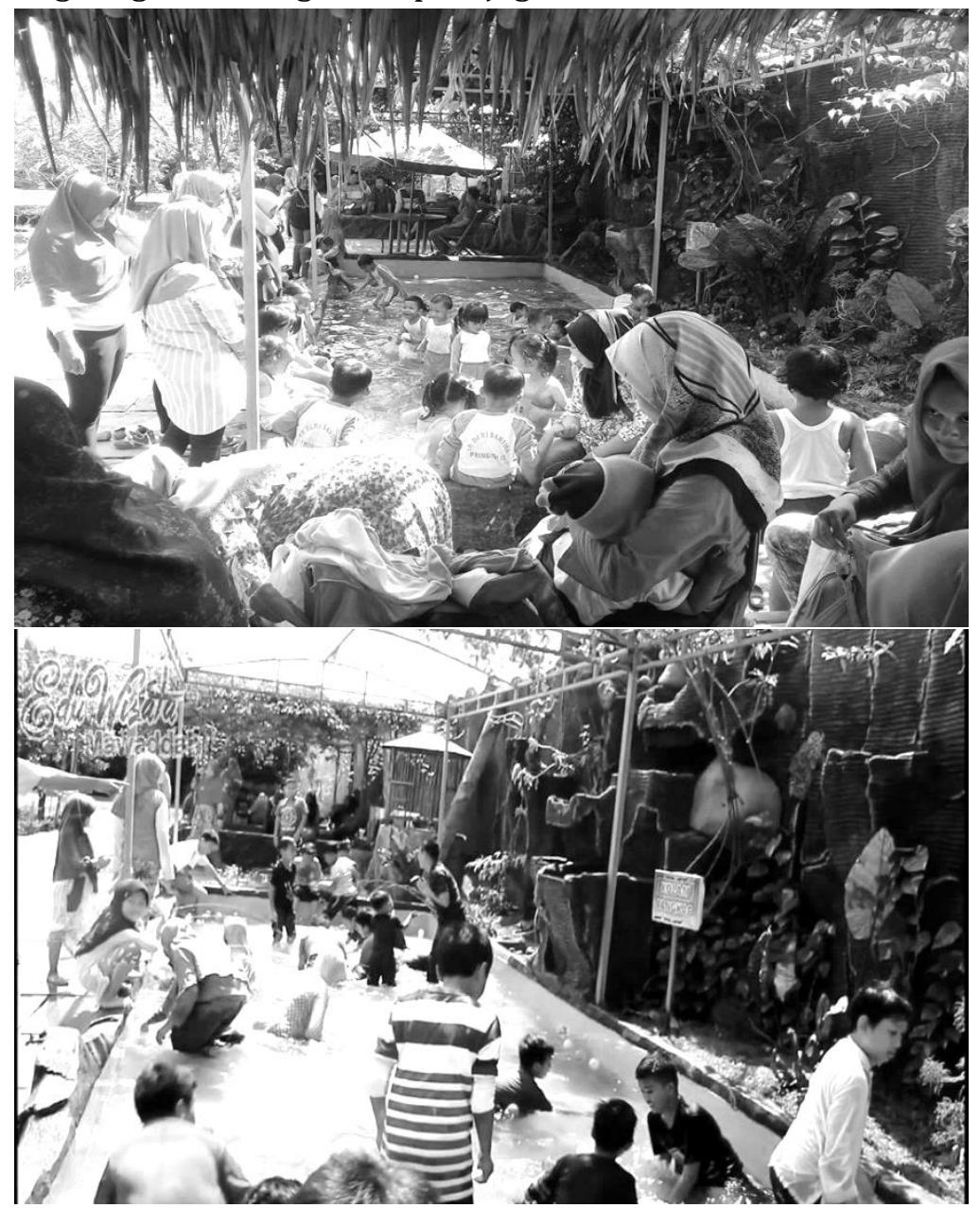

\section{e. Taman Kelinci}

Pesantren Al Mawaddah juga menyedikan taman kelinci, dimana anak bisa melihat langsung kehidupan kelinci. Pola saat kelinci makan, berkumpul dan tidur anak dapat mengamati dan bisa mengambil kesimpulan tentang pola kehidupan kelinci, serta tentunya anak dapat memegang langsung kelinci dan anak-anak menjadi senang. Dari sini anak diajarkan untuk menyayangi binatang.

are 


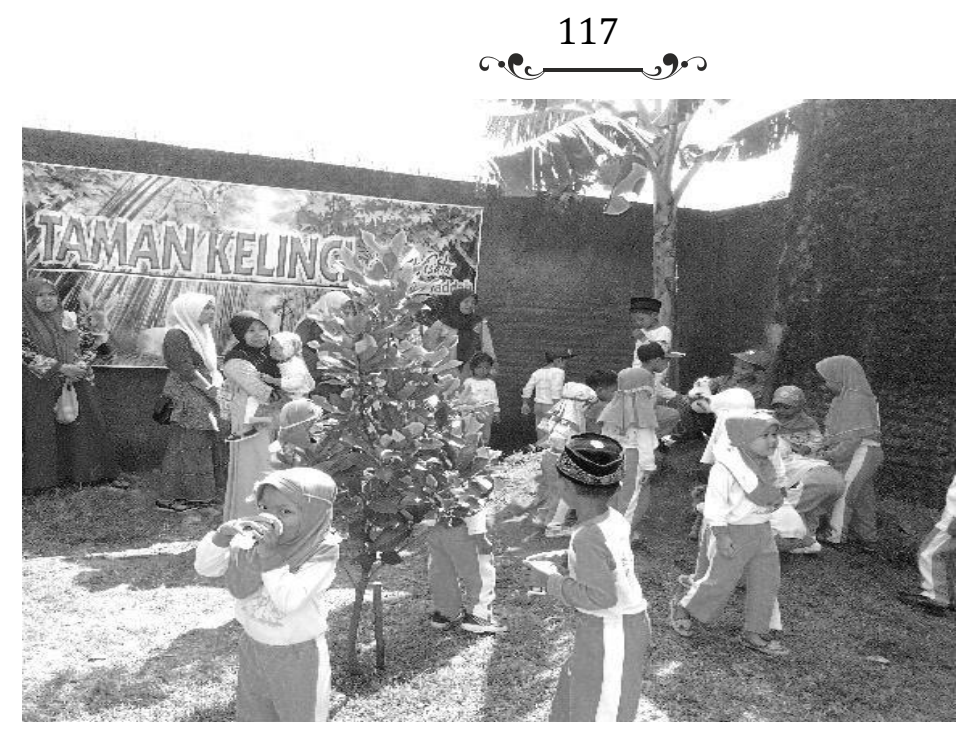

\section{Simpulan}

Kegiatan belajar merupakan proses yang harus ada dan berlangsung sepanjang hidupnya (long life eduction). Proses belajar bisa terjadi karena adanya interaksi antara seseorang dengan lingkungannya. Hal ini karenatidak selamanya kegiatan pembelajaranberlangsung didalam kelas. Memberdayakan lingkungan sebagai media dalam belajar adalah hal yang menarik dan menyenangkan bagi siswa, tidak hanya pembelajaran secara langsung terhadap alam akan tetapi siswa diajarkan bagaimana cara mengenal dan mengetahui kekuasaan Allah SWT secara langsung, ini karena penanaman nilai religius sangatlah penting bagi anak sekolah dasar. Hasil penelitian menunjukkan bahwa; Tema yang terkait dengan media yang ditawarkan Al Mawaddah yakni mata pelajaran Aqidah Akhlak dalam tema Asmaul Husna dalam lafalnya "Al Khaliq" (Sang Pencipta), selain itu juga termuat dalam mata pelajaran Ilmu Pengetahuan Alam (IPA) dalam tema tumbuhan dan binatang. Melalui media lingkungan alam tersebut akan membantu guru dalam menjelaskan materi terkait tema-tema tersebut. konsep yang ditawarkan pondok pesantren Al Mawaddah untuk mengenalkan kekuasaan Allah meliputi; budidaya buah naga, apotek hidup, hidroponik, taman kelinci, terapi ikan garra rafa. 


\section{recus 118}

\section{Daftar Pustaka}

Baharun, Hasan. 2015. Penerapan Pembelajaran Active Learning Untuk Meningkatkan Hasil Belajar Siswa Di Madrasah. Jurnal Pendidikan Vol. 2 No. 2

Baharun, Hasan. 2016. Pengembangan Media Pembelajaran PAI Berbasis Lingkungan Melalui Model Assure. Jurnal Cendekia Vol.14 No.2.

Chatib, Munif. 2014. Sekolahnya Manusia. Jakarta: Ikapi.

Daryanto. 2013. Media Pembelajaran: Peranannya Sangat Penting Dalam Mencapai Tujuan Pembelajaran. Yogyakarta: GavaMedia.

Djamarah, Saiful Bahri. dkk. 2006. Strategi Belajar Mengajar. Jakarta: Rineka Cipta

Fathurrohman, Pupuh dan M. Sobri Sutikno, 2009, Strategi Belajar Mengajar Melalui Penanaman Konsep Umum dan Konsep Islami. Bandung: P.T Refika Aditama.

Hamalik, Oemar. 2003. Psikologi Belajar Mengajar. Bandung: Sinar Baru.

Hurlock, Elizabeth B. 2009. Psikologi Perkembangaa: suatu pendekatan sepanjang rentang kehidupan. Bandung: Erlangga.

Ifrianti, Syofnidah. 2016, "Pemanfaatan lingkungan sekitar sebagai media pembelajaran IPS untuk meningkatkan aktivitas dan hasil belajar anak kelas III MIN 10 Bandar Lampung", Terampil, Jurnal Pendidikan dan Pembelajaran Dasar Volume 3 Nomor 2

LAL, Anshori. 2012. Pendidikan Islam Transformatif. Jakarta : Ikapi.

Monks, F.J. 2014. Psikologi Perkembangan. Yogyakarta: Gadjah Mad University Press.

Nata, Abuddin. 2010. Ilmu Pendidika Islam. Jakarta : Prenadamedia Grup.

Pengembangan Wirausaha Santri Di Pondok Pesantren Al-Mawaddah Honggosoco Jekulo Kudus.

Ramadhani, Tahmid Sabri, Siti Halidjah, tt, "Pemanfaatan Media Lingkungan Sekitar Untuk Meningkatkan Keterampilan Menulis Karangan Deskripsi Siswa Kelas V" Artikel Penelitian

Rohmah, Noer. 2015. Psikologi Pendidikan. Yogyakarta: Kalimedia 


$$
119
$$

Roso Sugiyanto, 2015, “Pemanfaatan Media Lingkungan Untuk Meningkatkan Hasil Belajar IPS Siswa Sekolah Dasar Negeri 4 Tanah Putih Kecamatan Telawang Kabupaten Kotawaringin Timur, Jurnal Geotadulako Vol. 3 No. 6

Sadiman, Arief S, R, Raharjo, dkk. 2012. Media Pendidikan (pengertian, pengembangan, dan pemanfaatanya). Jakarta: PT RajaGrafindo Persada.

Sanjaya, Wina. 2005. KurikulumDanPembelajaran. Jakarta: PrenadaMediaGroup.

Sanjaya, Wina. 2006. Strategi Pembelajaran berorientasi standar proses pendidikan. Jakarta: PrenadaMediaGroup.

Sugiyono, 2016, Metode Penelitian Kuantitatif, Kualitatif, dan Kombinasi (Mixed Methods), Bandung: Alfabeta

Uno, HamzahB. 2011. Tekhnologi KomunikasiDanInformasiPembelajaran. Jakarta: BumiAksara.

Wiyani, Novan Ardy. 2013. Desain Pembelajaran Peendidikan: tata rancang pembelajaran menuju pencapaian kompetensi. Yogyakarta: Ar-ruzz Media. 